\title{
PENGARUH STRATEGI PEMBELAJARAN KOOPERATIF STAD DAN GAYA BELAJAR TERHADAP HASIL BELAJAR PENDIDIKAN AGAMA ISLAM SISWA SEKOLAH DASAR NEGERI 054938 ALUR DUA KECAMATAN SEI LEPAN PANGKALAN BRANDAN KABUPATEN LANGKAT
}

\section{Uthman \\ Penulis adalah Guru Sekolah Dasar Negeri 054938 Alur Dua Kecamatan Sei Lepan Pangkalan Brandan Kabupaten Langkat}

\begin{abstract}
The objectives of this research were to discover: (1) the difference in learning achievement of Islam Religion Education of students taught by cooperative instructional strategy STAD type and student taught by expository instructional strategy, (2) the a difference of learning style Islam Religion education with visual, auditory and kinesthetic, learning style, and (3) the interaction between instructional strategy and learning style in affecting learning achievement of learning style Islam religion education. The population was Grade V students of Primary School Inti Number SD Negeri 054938 Alur Dua Sei Lepan Pangkalan Brandan Langkat regency consisting of three classes. The sample chosen for instructional class using STAD was class Vc with 40 students, while those taught by expository was class $\mathrm{Vb}$ with 40 students. The results of the findings were: (1) the average of Islam Religion Education of students taught by STAD instructional strategy $(\bar{X}=29,95)$ was higher than the average of students taught by expositoyi instructional strategy $(\bar{X}=28,62)$ with $\mathrm{F}_{\text {count }}$ $\left.=12,46>F_{\text {table }}=3,972\right)$, the avarage learning achievement of Islam religion education with kinesthetic learning style $(\bar{X}=29,77)$ and visual learning style $(\bar{X}=25.35)$ with $\mathrm{F}_{\text {count }}=5,92>\mathrm{F}_{\text {table }}=3,972$, and (3) there was an interaction between instructional strategy and learning style toward students learning achievement Islam Religion education with $\mathrm{F}_{\text {count }}=23.84>\mathrm{F}_{\text {table }}=3,972$.
\end{abstract}

Kata Kunci: STAD, Gaya Belajar, Hasil

\section{PENDAHULUAN}

Pendidikan Agama Islam (PAI) merupakan salah satu bagian dalam mencapai tujuan pendidikan untuk menjadikan manusia yang kamil (sempurna). Pendidikan sebagai transfer of knowledge merupakan mata tombak utama dalam menyampaikan ajaran-ajaran yang tertuang dalam Al-Qur'an dan Al-Hadits sebagai sumber utama ajaran agama Islam. Di mana dengan adanya pendidikan ini maka ajaran-ajaran agama dapat diwariskan kepada generasi berikutnya dan benar-benar terinternalisasi dalam diri generasi mendatang.

Penerapan strategi yang tepat maka materi ajar dalam PAI dapat diserap oleh anak didik dengan sebaik-baiknya. Strategi yang tepat akan menentukan efektifitas dan 
efisiensi pembelajaran. Sebagai seorang guru pendidik agama Islam maka perlu mengetahui strategi-strategi dalam PAI. Dengan mengetahui strategi-strategi tersebut maka guru diharapkan mampu menyampaikan materi-materi ajaran agama Islam dengan berbagai variasi sehingga tujuan pendidikan agama Islam dapat tercapai dengan lebih mudah.

Guru mempunyai peran yang sangat strategis dalam peningkatan mutu pendidikan di Indonesia. Mereka diharapkan dapat mengembangkan potensi yang dimiliki para siswa agar dapat menghayati dan mengamalkan ajaran agama Islam dalam kehidupan sehari-hari. Mereka adalah figur yang utama dalam menanamkan nilai-nilai ajaran agama Islam dalam kerangka pembentukan sikap dan watak, serta perilaku akhlakul karimah melalui berbagai strategi pembelajaran yang dikembangkan di sekolah.

Upaya untuk merealisasikan pelaksanaan PAI, guru dituntut untuk menguasai pengetahuan yang memadai dan teknik-teknik mengajar yang baik agar ia mampu menciptakan suasana pengajaran yang efektif dan efisien atau dapat mencapai hasil yang sesuai dengan tujuan yang diharapkan. Sebagian besar teknik dan suasana pengajaran di sekolah-sekolah membuat siswa harus mau mendengarkan, mau menerima seluruh informasi dan mentaati segala perlakuan gurunya. PAI dipelajari di bangku sekolah terkadang tidak integratif dengan kehidupan sehari-hari. Bahkan tak jarang realitas sehari-hari yang mereka saksikan bertolak belakang dengan pelajaran di sekolah. Budaya semacam ini pada gilirannya membuat siswa tidak mampu mengaktivasi kemampuan intelektualitasnya, sehingga mereka tidak memiliki keberanian menyampaikan pendapat, lemah penalaran dan tergantung pada orang lain.

Strategi pembelajaran yang digunakan di kelas memerlukan keahlian tersendiri. Seorang pendidik harus pandai memilih strategi pembelajaran yang akan dipergunakan, strategi pembelajaran yang diberikan haruslah melihat kepada karakteristik siswa sehingga dapat memotivasi serta memberikan kepuasan bagi anak didiknya seperti hasil atau prestasi belajar siswa akan semakin meningkat.

Strategi pembelajaran dibutuhkan guna memperoleh hasil belajar seperti yang diharapkan maka dibutuhkan strategi pembelajaran yang mampu untuk membuat siswa tertarik dan mengkondisikan pembelajaran itu berpusat padanya (student centered) dalam proses pembelajaran tersebut. Strategi pembelajaran kooperatif Student Team Achievement Division (STAD) adalah strategi pembelajaran yang melibatkan siswa di 
dalam suatu kelompok, agar mereka dapat bekerjasama berbagi pengetahuan sesuai dengan karakteristik siswa SD yang pada dasarnya mereka itu belajar dengan teman sebaya dari berbagai latar belakang yang berbeda dan cara belajar siswa sesuai dengan gaya belajarnya masing-masing. Strategi pembelajaran kooperatif STAD ini dianggap dapat memperbaiki hasil belajar siswa yang selama ini didominasi strategi pembelajaran ekspositori di mana guru sebagai pusat pembelajaran siswa.

Karakteristik siswa yang merupakan faktor yang harus diperhatikan guru yang meliputi motivasi, minat, kemampuan awal, gaya belajar dan sebagainya. Peneliti memfokus pada karakteristik siswa pada aspek gaya belajar, dalam ini gaya belajar yang dibahas dalam penelitian ini adalah gaya belajar Visual, Auditori dan Kinestetik. Masing-masing siswa memiliki gaya belajar yang tidak sama satu dengan yang lainnya, oleh karena itu dalam suatu proses pembelajaran, seorang tenaga pengajar hendaknya mampu mengetahui dan memahami kecenderungan gaya belajar yang telah dimiliki siswa. Dengan mengetahui kecenderungan gaya belajar siswa, maka seorang guru dapat menyesuaikan, menyusun dan membuat materi ajar yang relevan untuk membantu dan mengarahkan kesiapan siswa untuk menerima materi pelajaran.

Hasil penelitian menunjukkan perbedaan gaya belajar pada diri siswa memberikan pengaruh kepada aktivitas maupun hasil belajar, diantaranya: (1) hasil penelitian Nurellah, Panjaitan, Maulana (2016) menunjukkan penerapan pembelajaran visual, auditori dan kinestetik dapat meningkatkan hasil belajar siswa pada materi pesawat sederhana siswa sekolah dasar, di mana akumulasi aktivitas siswa dari ketiga aspek yang mencapai kategori sangat baik pada siklus I 16\%, siklus II 56\%, dan siklus III 92\% demikian juga dengan hasil belajar siswa pada siklus I 24\%, siklus II 60\%, dan siklus III mencapai 88\%, (2) hasil penelitian Bire, Geradus, Bire (2014) menunjukkan sumbangan relatif gaya belajar visual, auditorial, dan kinestetik terhadap prestasi belajar siswa sebesar $34,8 \%$. Sumbangan relatif masing-masing terhadap prestasi belajar, yakni: gaya belajar visual 26,4\%, gaya belajar auditorial 24,2\%, dan gaya belajar kinestetik 26,2\%, dan (3) hasil penelitian Khoeron, Sumarna, dan Permana (2014) menunjukkan bahwa gaya belajar mempunyai hubungan terhadap prestasi belajar. Gaya belajar berpengaruh signifikan terhadap prestasi belajar. Gaya belajar mempunyai kontribusi atau pengaruh sebesar 52\% terhadap prestasi belajar peserta didik dan sisanya $48 \%$ dipengaruhi oleh variabel lain yang tidak di analisis dalam model. 


\section{KAJIAN TEORI}

Hilgard dan Bower sebagaimana dikutip Purwanto (1998:84) menyatakan belajar berhubungan dengan perubahan tingkah laku seseorang terhadap situasi tertentu yang disebabkan oleh pengalamannya yang berulang-ulang dalam situasi tertentu di mana perubahan tingkah laku itu tidak dapat dijelaskan atau dasar kecenderungan respon pembawaan, kematangan, atau keadaan-keadaan sesaat seseorang misalya kelelahan, pengaruh obat dan sebagainya.

Speard menyatakan:"learning is to observe, to read, to imitate, to try something themselves, to listen, and to follow direction (Suryabrata, 2002:231). Belajar itu adalah suatu kegiatan yang dilakukan secara terarah dengan cara mengamati, membaca, meniru, mencoba atau mempraktekkannya langsung, mendengar dan mengikuti arahan-arahan ataupun petunjuk yang diberikan. Selanjutnya Kingsley mengemukakan bahwa: "Learning is the process by which behavior (in the broader sense) is originated or changed through practice or training”. Belajar adalah proses di mana tingkah laku (dalam arti luas) ditimbulkan atau diubah melalui latihan atau pelatihan (Sumanto, 1984: 99).

Purwanto (1998:85) menyatakan belajar merupakan suatu perubahan yang terjadi melalui latihan dan pengalaman, dalam arti perubahan-perubahan yang disebabkan oleh pertumbuhan atau kematangan tidak dianggap sebagai hasil belajar. Selanjutnya menurut Sudjana (1996:5) belajar adalah suatu proses yang ditandai dengan adanya perubahan pada diri seseorang. Perubahan sebagai hasil dari proses belajar dapat ditunjukkan dalam berbagai bentuk seperti berubah pengetahuan, pemahaman, sikap dan tingkah laku, keterampilan, kecakapan, kebiasaan serta perubahan aspek-aspek-aspek lain yang ada pada individu yang belajar.

Hasil belajar dijelaskan Rusmono (2012:10) yaitu perubahan perilaku individu yang meliputi ranah kognitif, afektif, dan psikomotor. Perubahan perilaku tersebut diperoleh setelah siswa menyelesaikan program pembelajarannya melalui interaksi dengan berbagai sumber belajar dan lingkungan belajar.

Kingsley membagi tiga macam hasil belajar yakni: (1) keterampilan dan kebiasaan, (2) pengetahuan dan pengertian, dan (3) sikap dan cita-cita yang masingmaisng golongan dapat diisi dengan bahan yang ditetapkan dalam kurikulum sekolah (Sudjana, 2002:45). Selanjutnya Gagne sebagaimana dikuti Sudjana (2002:45) 
menyatakan tipe hasil belajar yakni: (1) informasi verbal, (2) kemampuan intelektual, (3) strategi kognitif, (4) sikap, dan (5) kemampuan motorik.

Idris (2011:102) menjelaskan taksonomi Bloom yang membagi tipe hasil belajar adalah kognitif, afektif dan psikomotorik. Ranah kognitif meliputi tujuan pendidikan yang berkenaan dengan ingatan atau pengenalan terhadap pengetahuan dan pengembangan kemampuan intelektual dan keterampilan berpikir yang terbagi menjadi enam jenjang, yaitu: (1) pengetahuan (knowledge), (2) pemahaman (comprehension), (3) penerapan (application), (4) analisis (analysis), (5) sistesis (synthesis), dan (6 ) penilaian (evaluation). Ranah afektif berkenaan dengan minat, sikap dan nilai serta pengembangan penghargaan dan penyesuaian diri yang terbagi lima jenjang, yakni: (1) penerimaan (receiving), (2) menanggapi (responding), (3) menilai (valuing), (4) mengorganisasikan (organization), dan (5) karakterisasi (characterization). Ranah psikomotorik yaitu: (1) persepsi, (2) kesiapan, (3) gerakan terbimbing, (4) gerakan terbiasa, (5) gerakan kompleks, (6) penyesuaian pola gerakan, dan (7) kreativitas.

Hasil belajar PAI di sekolah umum dijelaskan bahwa PAI adalah usaha sadar untuk menyiapkan siswa dalam menyakini, memahami, menghayati dan mengamalkan agama Islam melalui kegiatan bimbingan, pengajaran dan atau latihan dengan memperlihatkan tuntunan untuk menghormati agama lain dalam hubungan kerukunan antar umat beragama dalam masyarakat untuk mewujudkan persatuan nasional. (Muhaimin, 2001:75).

Lie (2004: 28) menyatakan bahwa cooperative learning adalah model pembelajaran gotong royong, yaitu sistem pembelajaran yang memberi kesempatan kepada peserta didik untuk bekerjasama dengan siswa lain dalam tugas-tugas yang terstruktur. Strategi pembelajaran ini hanya berjalan kalau sudah terbentuk suatu kelompok atau suatu tim yang didalamnya siswa bekerja secara terarah untuk mencapai tujuan yang sudah ditentukan sebelumnya dengan jumlah anggota kelompok tertentu.

Roger dan Johnson sebagaimana dikutip Lie (2004:31) menjelaskan lima unsur pembelajaran kooperatif (pembelajaran gotong royong) yang harus diterapkan, yaitu: (1) saling ketergantungan positif, (2) tanggung jawab perseorangan,/individual (3) tatap muka, (4) komunikasi antar anggota kelompok, dan (5) evaluasi proses kelompok. 
Lungdren sebagaimana dikutip Isjoni (2009:13) menjelaskan unsur-unsur dasar dalam pembelajaran kooperatif yaitu: (a) siswa harus memiliki persepsi bahwa mereka "tenggelam atau berenang bersama", (b) siswa harus memiliki tanggungjawab terhadap siswa atau peserta didik lain dalam kelompoknya, selain tanggungjawab terhadap diri sendiri dalam mempelajari materi yang dihadapi, (c) para siswa harus berpandangan bahwa mereka semua memiliki tujuan yang sama, (d) para siswa membagi tugas dan berbagi tanggungjawab di antara para anggota kelompok, (e) para siswa diberikan satu evaluasi atau penghargaan yang akan ikut berpengaruh terhadap evaluasi kelompok, (f) para siswa berbagi kepemimpinan sementara mereka memperoleh keterampilan bekerja sama selama belajar, dan (g) setiap siswa akan diminta mempertanggungjawabkan secara individual materi yang ditangani dalam kelompok kooperatif.

Salah satu model dalam pembelajaran kooperatif adalah Student Team Achievement Division (STAD). Slavin (2005:143) menjelaskan STAD merupakan salah satu model pembelajaran kooperatif yang paling sederhana dan merupakan model yang paling baik untuk permulaan bagi gutu yang baru menggunakan pendekatan kooperatif. Selanjutnya dijelaskan Slavin bahwa STAD terdiri dari atas lima komponen utama yaitu presentasi kelas, tim, kuis, skor kemajuan individual dan rekognisi tim.

Dalam STAD para siswa dibagi dalam tim belajar yang terdiri atas siswa orang yang berbeda-beda tingkat kemampuan, jenis kelamin dan latar belakang etniknya. Guru menyampaikan pelajaran, lalu siswa bekerja dalam tim mereka untuk memastikan bahwa anggota tim telah menguasai pelajaran. Selanjutnya, semua siswa mengerjakan kuis mengenai pelajaran tersebut secara individual, saat itu mereka tidak boleh saling bekerja sama. Dari kuis ini akan didapatkan skor individual dan rata-rata skor tim. Skor tim dihitung berdasarkan kemajuan yang dibuat oleh tiap anggota tim.

Al-Tabany (2014:118) menjelaskan persiapan di dalam melaksanakan pembelajaran kooperatif yaitu: (1) sebelum melaksanakan pembelajaran perlu dipersiapkan perangka pembelajaran meliputi rencana pelaksanaan pembelajaran (RPP), buku siswa, dan lembar kegiatan siswa, (2) menentukan anggota kelompok diusahakan agar kemampuan siswa dalam kelompok heterogen, dan kemampua antar satu kelompok dengan kelompok lainnya relatif homogen, (3) skor awal yang dapat digunakan adalah nilai ulangan sebelumnya. Skor ini dapat berubah setelah ada kuis, 
(4) pengaturan tempat duduk juga perlu dilakukan, hal ini dimaksudkan untuk menunjang keberhasilan pembelajaran. Apabila tidak ada pengaturan tempat duduk maka dapat menimbulkan kekacauan yang menyebabkan gagalnya pembelajaran, (5) untuk mencegah adanya hambatan pada pembelajaran kooperatif model STAD maka terlebih dahulu diadakan latihan kerjasama kelompok. Hal ini bertujuan untuk lebih jauh mengenalkan masing-masing individu dalam kelompok.

Strategi pembelajaran ekspositori adalah strategi pembelajaran yang menekankan kepada proses penyampaian materi secara verbal dari seorang guru kepada sekelompok siswa dengan maksud agar siswa dapat menguasai materi pelajaran secara optimal. Dalam strategi ini materi pelajaran disampaikan langsung oleh guru. Siswa tidak dituntut untuk menemukan materi itu. Materi pelajaran seakanakan sudah jadi. Karena strategi ekspositori lebih menekankan kepada proses bertutur, maka sering juga dinamakan strategi "chalk and talk". Killen sebagaimana dikutip Sanjaya (2014:179) menamakan strategi ekspositori ini dengan istilah strategi pembelajaran langsung (direct instruction)

Gunawan (2004:6) menjelaskan gaya belajar adalah cara yang lebih disukai dalam melakukan kegiatan berpikir, memproses dan mengerti suatu informasi. Selanjutnya gaya belajar menurut Nasution (2006:94) yaitu cara yang konsisten yang dilakukan oleh seorang murid dalam menangkap stimulus atau informasi, cara mengingat, berpikir dan memecahkan soal.

De Porter dam Hernacki, (2004:118) menjelaskan ciri-ciri siswa dengan gaya belajar kinestetik sebagai berikut: (1) berbicara dengan perlahan, (2) menanggapi perhatian fisik, (3) menyentuh orang untuk mendapat perhatian mereka, (4). berdiri dekat ketika berbicara dengan orang, (5) selalu berorientasi pada fisik dan banyak bergerak, (6) menghafal dengan cara berjalan dan melihat, (7) menggunakan jari sebagai petunjuk saat membaca, (8) banyak menggunakan isyarat tubuh, (9) mempunyai perkembangan awal otot-otot yang besar, (10) sulit mengingat peta kecuali jika dirinya pernah berada di tempat itu, (11) kemungkinan tulisannya jelek, dan (12) tidak dapat duduk diam untuk waktu lama.

\section{METODOLOGI PENELITIAN}

Metode penelitian yang digunakan adalah quasi eksperiment (eksperimen semu) yang bertujuan untuk mengetahui pengaruh strategi pembelajaran dan gaya 
belajar terhadap hasil belajar pendidikan agama Islam. Penelitian ini menggunakan desain faktorial 2 x 3 . Populasi dalam penelitian adalah seluruh siswa kelas V (lima) SDN 054938 Alur Dua Sei Lepan Pangkalan Brandan Kabupaten Langkat tahun pelajaran 2017/2018 yang terdiri dari 3 (tiga) kelas yang berjumlah 103 siswa. Teknik penentuan sampel digunakan cluster random sampling (pengambilan sampel secara acak berdasarkan kelas/kelompok). Teknik ini dipilih karena yang disampling dari populasi adalah jumlah kelas (sebanyak 3 kelas) bukan jumlah siswa dalam populasi. Sampel yang diambil terdiri dari dua kelompok yaitu, kelompok kelas dilakukan pembelajaran menggunakan strategi pembelajaran kooperatif STAD dan satu kelas lagi menggunakan strategi pembelajaran ekspositori. Kelas terpilih adalah kelas Vc, untuk kertas yang tidak di cabut maka ditetapkan sebagai kelas dengan strategi pembelajaran ekspositori, dalam hal ini terpilih kelas $\mathrm{Vb}$.

\section{TEMUAN DAN PEMBAHASAN}

Rata-rata hasil belajar Pendidikan Agama Islam siswa SDN 054938 Alur Dua Sei Lepan yang diajar dengan strategi pembelajaran Student Team Achievement Division $(\bar{X}=29,95)$ lebih baik daripada rata-rata hasil belajar siswa yang diajar dengan strategi pembelajaran ekspositori $(\bar{X}=28,62)$. Temuan ini menunjukkan bahwa strategi Student Team Achievement Division terbukti efektif dapat meningkatkan hasil belajar siswa secara keseluruhan baik untuk kelompok siswa dengan gaya belajar visual, auditori maupun kinestetik. Dari hasil temuan ini menunjukkan bahwa untuk mengajarkan materi ajar Pendidikan Agama Islam siswa SDN 054938 Alur Dua Sei Lepan lebih baik menggunakan strategi pembelajaran Student Team Achievement Division daripada dengan strategi pembelajaran ekspositori.

Pelaksanaan pembelajaran kooperatif Student Team Achievement Division diajarkan keterampilan- keterampilan khusus agar dapat bekerja sama dengan baik di dalam kelompoknya, seperti menjadi pendengar yang baik, siswa diberi lembar kegiatan yang berisi pertanyaan atau tugas yang direncanakan untuk diajarkan. Selama kerja kelompok, tugas anggota kelompok adalah mencapai ketuntasan .

Penerapan strategi pembelajaran kooperatif Student Team Achievement Division memberikan dampak kepada pencapaian hasil belajar Pendidikan Agama Islam meningkat karena dengan belajar secara kelompok dalam situasi yang heterogen 
kemampuannya membuat siswa akan dapat saling mempengaruhi dan saling bersosialisasi sehingga memicu aktivitas belajar mereka menjadi lebih baik, mereka dapat memahami konsep-konsep yang mungkin sulit mereka mengerti bila mereka hanya mempelajarinya secara individual.

Belajar dalam kelompok membuat mereka saling berinteraksi, yang lebih pintar dapat memberi penjelasan kepada yang lamban, dan sebaliknya yang lamban bisa bertanya kepada yang faham sehingga mereka dapat saling mengisi dan memotivasi diri mereka sendiri untuk dapat bekerja sama tetapi juga bertanggung jawab untuk memperbaiki nilai masing-masing.

Penerapan strategi pembelajaran Student Team Achievement Division dalam pembelajaran Pendidikan Agama Islam maka dapat diduga siswa akan lebih terbantu dalam kegiatan belajarnya, membina kerjasama yang baik melalui pendekatan strategi pembelajaran Student Team Achievement Division dipastikan pemahaman dan perolehan nilai dari mata pelajaran Pendidikan Agama Islam akan dapat terangkat karena tujuan dari Strategi pembelajaran Student Team Achievement Division Student Team Achievement Division ini adalah memperbaiki prestasi belajar secara akademik, penerimaan perbedaan individu dan pengembangan ketrampilan social sebagaimana yang telah diuraikan sebelumnya.

Jika diperhatikan lebih lanjut bahwa dalam strategi pembelajaran Student Team Achievement Division rata-rata hasil belajar siswa dengan gaya belajar kinestetik $(\bar{X}=$ 31,5) lebih tinggi daripada hasil belajar siswa dengan gaya belajar visual $(\bar{X}=29,14)$ maupun siswa dengan gaya belajar auditori $(\bar{X}=29,86)$. Sedangkan pada strategi pembelajaran ekspositori, rata-rata hasil belajar siswa dengan gaya belajar auditori $(\bar{X}=30,69)$ lebih tinggi daripada hasil siswa dengan gaya belajar visual $(\bar{X}=26)$ maupun dengan gaya belajar kinestetik ( $\bar{X}=29,80)$.

Hasil penelitian menunjukkan semua hipotesis penelitian yaitu: (1) hasil belajar Pendidikan Agama Islam siswa SDN 054938 Alur Dua Sei Lepan yang diajar dengan strategi pembelajaran Student Team Achievement Division lebih tinggi daripada hasil belajar siswa yang diajar dengan strategi pembelajaran ekspositori, (2) hasil belajar Pendidikan Agama Islam siswa SDN 054938 Alur Dua Sei Lepan dengan gaya belajar visual, auditori dan kinestetik berbeda signifikan, dan (3) terdapat interaksi antara strategi pembelajaran dan gaya belajar dalam memberikan pengaruh terhadap 
hasil belajar Pendidikan Agama Islam siswa SDN 054938 Alur Dua Sei Lepan, dapatlah diterima ketiga-tiganya.

Hipotesis pertama yang menyatakan hasil belajar Pendidikan Agama Islam siswa SDN 054938 Alur Dua Sei Lepan antara yang diajar dengan strategi pembelajaran Student Team Achievement Division lebih tinggi daripada hasil belajar Pendidikan Agama Islam siswa SDN 054938 Alur Dua Sei Lepan yang diajar dengan strategi pembelajaran ekspositori.

Pengujian hipotesis kedua menunjukkan bahwa hasil belajar Pendidikan Agama Islam siswa SDN 054938 Alur Dua Sei Lepan dengan kecenderungan gaya belajar visual, auditori dan kinestetik memiliki perbedaan hasil belajar yang signifikan. Hasil ini membuktikan bahwa gaya belajar signifikan untuk membedakan hasil belajar. Hasil analisis data secara keseluruhan diperoleh rata-rata hasil belajar Pendidikan Agama Islam siswa SDN 054938 Alur Dua Sei Lepan dengan gaya belajar kinestetik lebih tinggi daripada hasil belajar Pendidikan Agama Islam siswa SDN 054938 Alur Dua Sei Lepan dengan gaya belajar visual dan auditori. Hal ini berindikasi bahwa siswa yang dengan gaya belajar kinestetik secara rata-rata mempunyai hasil belajar Pendidikan Agama Islam siswa SDN 054938 Alur Dua Sei Lepan lebih baik dibandingkan dengan siswa dengan gaya belajar visual dan auditori.

Pengujian hipotesis ketiga terdapat interaksi antara strategi pembelajaran dan gaya belajar dalam mempengaruhi hasil belajar Pendidikan Agama Islam siswa SDN 054938 Alur Dua Sei Lepan. Apabila dilihat rata-rata hasil belajar Pendidikan Agama Islam pada kelompok siswa dengan gaya belajar visual dan kinestetik lebih baik diajar dengan strategi pembelajaran Student Team Achievement Division dengan strategi pembelajaran ekspositori.

Rata-rata hasil belajar Pendidikan Agama Islam pada kelompok siswa dengan gaya belajar auditori lebih baik diajarkan dengan strategi pembelajaran ekspositori dibandingkan dengan strategi pembelajaran Student Team Achievement Division.

Kemudian terdapat interaksi strategi pembelajaran dan gaya belajar terhadap hasil belajar, hal ini terlihat dari: (a) strategi pembelajaran Student Team Achievement Division memberikan hasil belajar yang lebih tinggi pada siswa dengan gaya belajar kinestetik daripada siswa dengan gaya belajar visual dan auditori (b) strategi pembelajaran ekspositori memberikan hasil belajar yang lebih tinggi pada siswa dengan gaya belajar auditori daripada siswa dengan gaya belajar visual dan kinestetik. 
Hal ini diketahui dari rata-rata skor siswa yang diajar dengan strategi pembelajaran Student Team Achievement Division pada siswa dengan gaya belajar kinestetik $(\bar{X}=$ $31,5)$ lebih tinggi dari siswa dengan gaya belajar visual $(\bar{X}=29,14)$ maupun dengan gaya belajar auditori ( $\bar{X}=29,86$ ) dan rata-rata hasil belajar siswa yang diajar dengan strategi pembelajaran ekspositori pada siswa dengan gaya belajar auditori $(\bar{X}=30,69)$ lebih tinggi dari rata-rata hasil belajar siswa dengan gaya belajar visual $(\bar{X}=26)$ maupun dengan gaya belajar kinestetik $(\bar{X}=29,80)$.

\section{SIMPULAN DAN REKOMENDASI}

Simpulan-simpulan yang dapat ditarik dari hasil pengujian hipotesis adalah sebagai berikut:

1. Rata-rata hasil belajar Pendidikan Agama Islam siswa yang diajar dengan strategi pembelajaran Student Team Achievement Division dengan strategi pembelajaran ekspositori. Dalam hal ini hasil belajar Pendidikan Agama Islam siswa yang diajar dengan strategi pembelajaran Student Team Achievement Division $(\bar{X}=29,95)$ lebih tinggi dibandingkan yang diajar dengan strategi pembelajaran ekspositori $(\bar{X}=28,62)$. Hal ini juga dibuktikan dengan harga $\mathrm{F}_{\text {hitung }} 12,46>\mathrm{F}_{\text {tabel }} 3,972$.

2. Terdapat perbedaan rata-rata hasil belajar Pendidikan Agama Islam siswa dengan gaya belajar visual $(\bar{X}=25,35)$, auditori $(\bar{X}=29,77)$ dan kinestetik $(\bar{X}=28,38)$ baik yang diajar dengan strategi pembelajaran Student Team Achievement Division maupun strategi ekspositori berbeda secara signifikan. Hal ini juga dibuktikan dengan harga $\mathrm{F}_{\text {hitung }} 5,92>\mathrm{F}_{\text {tabel }} 3,972$.

3. Terdapat interaksi antara strategi pembelajaran dan gaya belajar yang memberikan perbedaan pengaruh terhadap hasil belajar Pendidikan Agama Islam. Hal ini dibuktikan dengan harga $F_{\text {hitung }} 23,84>F_{\text {tabel }} 3,972$.

Rekomendasi yang dapat disampaikan sehubungan dengn temuan penelitian ini adalah: :

1. Strategi pembelajaran dan karakteristik siswa merupakan suatu komponen yang dapat menentukan dan mempengaruhi hasil belajar. Oleh karena itu guru sebagai perancang pembelajaran memperhatikan karakteristik siswa dalam 
merancamg pembelajaran sehingga dengan demikian guru dapat menetapkan pilihan strategi pembelajaran yang lebih sesuai untuk dilaksanakan.

2. Strategi pembelajaran Student Team Achievement Division memberikan hasil belajar yang lebih tinggi dalam mata pelajaran Pendidikan Agama Islam dibandingkan dengan strategi pembelajaran ekspositori. Oleh karena itu bagi guru disarankan dalam kegiatan pembelajaran perlu menerapkan strategi pembelajaran Student Team Achievement Division.

3. Bagi siswa dengan gaya belajar visual dan kinestetik disarankan untuk menggunakan strategi pembelajaran Student Team Achievement Division, sedangkan bagi siswa dengan gaya belajar auditori disarankan menggunakan strategi pembelajaran ekspositori.

4. Karakteristik siswa yang diteliti dari peneliian ini hanya terbatas kepada gaya belajar dan pada hanya diterapkan pada mata pelajaran Pendidikan Agama Islam dalam ranah kognitif. Untuk itu kepada peneliti lain disarankan untuk meneliti karakteristik siswa yang lain misalnya kemandirian, gaya kognitif, kemampuan awal, disarankan untuk peneliti lain dapat meneliti dalam bidang studi lainnya.

\section{DAFTAR PUSTAKA}

Al-Tabany, Trianto Ibnu Badar. Mendesain Model Pembelajaran Inovatif, Progesif, Dan Kontekstula. Jakarta: Prenada Media Group, 2014.

De Porter. Bobbi dan Mike, Hernacki. Quantum Learning. Membiasakan Belajar Nyaman dan Menyenangkan. Penerjemah. Alwiyah Abdurrahman. Bandung: Kaifa, 2003.

Gunawan, Adi W. Genius Learning Strategy. Jakarta: Grasindo, 2004.

Isjoni, Cooperative Learning Efektivitas Pembelajaran Kelompok, Bandung: Alfabeta, 2009.

Lie, Anita. Cooperative Learning. Mempraktekkan Cooperative Learning di Ruangruang kelas. Jakarta: Grasindo, 2004.

Muhaimin. Paradigma Pendidikan Islam. Upaya Mengefektifkan Pendidikan Agama Islam di Sekolah. Bandung: Remaja Rosdakarya, 2001.

Nasution, S. 2000. Dikdaktik Asas-Asas Mengajar. Jakarta: Bumi Aksara, 2000.

Rusmono, Strategi Pembelajaran Dengan Problem Based Learning Itu Perlu Untuk Meningkatkan Porfesionalitas Guru. Bogor: Ghalia Indonesia, 2012.

Sanjaya, Wina. Strategi Pembelajaran, Berorientasi Standar Proses Pendidikan. Jakarta: Prenada Media Group, 2014.

Sudjana, Nana. Cara Belajar Aktif Dalam Proses Belajar Mengajar. Bandung: Sinar Baru Algensindo, 1996.

Suryabrata, Sumadi. Psikologi Pendidikan. Jakarta: Rajagrafindo Persada, 2002. 